Vera A. Hartdegen, Maximilian S. Hofmayer, Konstantin Karaghiosoff and Thomas M. Klapötke*

\title{
Synthesis and characterization of allyl- and vinyl- substituted 1,2-bis(tetrazolo)ethanes as polymeric precursors
}

DOI 10.1515/znb-2016-0146

Received June 14, 2016; accepted July 13, 2016

\begin{abstract}
On the basis of 1,2-bis(5-tetrazolo)ethane (BTE) the corresponding twofold vinyl and allyl $N$-substituted derivatives were synthesized using 1,2-dibromoethane and allyl bromide, respectively. The compounds were obtained as two different constitutional isomers. Both species were analyzed using NMR and IR spectroscopy, elemental analysis, as well as mass spectrometry. In the case of the diallyl bistetrazoles, the two isomers were characterized using 2D NMR spectroscopy. The synthesis of the divinyl compounds gave crystals of the $2,2^{\prime}$ - $N$-substituted isomer, which were analyzed by single-crystal X-ray diffraction. The thermal stability of the compounds was determined using differential scanning calorimetry (DSC) and gave decomposition temperatures around $190^{\circ} \mathrm{C}$ and $230^{\circ} \mathrm{C}$. For the investigation of the inherent energetic potential, sensitivities toward physical stimuli and detonation parameters were determined. The compounds turned out to be insensitive toward friction and impact and possess moderate energetic properties.
\end{abstract}

Keywords: allyl; 2D NMR spectroscopy; tetrazole; thermal properties; vinyl.

Dedicated to: Professor Dr. Jürgen Evers on the occasion of his $75^{\text {th }}$ birthday.

\section{Introduction}

In the broad field of heterocyclic chemistry, heterocycles containing nitrogen make fascinating research objects. Among these nitrogen rich compounds, especially tetrazoles stand out due to their broad field of applications.

*Corresponding author: Thomas M. Klapötke, Department of Chemistry, Ludwig-Maximilian University of Munich, Butenandtstr. 5-13 (D), 81377 Munich, Germany, Fax: +49-89-2180-77492, E-mail:tmk@cup.uni-muenchen.de

Vera A. Hartdegen, Maximilian S. Hofmayer and Konstantin Karaghiosoff: Department of Chemistry, Ludwig-Maximilian University of Munich, Butenandtstr. 5-13 (D), 81377 Munich, Germany
They find use in pharmaceutical [1-4] and biomedical applications [5-7], as well as in energetic materials or gasgenerating agents $[8,9]$ for both, civil and military applications. In fact, tetrazoles are applied in every subfield of energetic materials, primary explosives [10-12], secondary explosives [13], propellants [14-22] as well as pyrotechnics [23-26]. Besides this, on the basis of tetrazoles, polymers were developed for the use as binders in energetic compositions [27-29]. Here, tetrazoles are well suited as monomeric units for these kinds of polymers, due to their high nitrogen content (up to $>80 \%$ ), good thermal stability, along with their energetic character [29]. Examples of tetrazole-based polymers are poly(vinyltetrazole) [30], poly(1-vinyl-1H-hydroxytetrazole) [30] or a polycondensate with $N^{1}$-[1-(4-aminophenyl)-1H-tetrazol-5-yl] benzene-1,4-diamine [31]. To date, most of the tetrazolecontaining polymers are synthesized via radical polymerization. Herein, we report the syntheses of bistetrazolo derivatives with twofold double bond functionalities, which offer diverse possibilities for further (polymeric) processing.

\section{Results and discussion}

\subsection{Syntheses}

On the basis of 1,2-bis(tetrazole-5-yl)ethane (BTE, 1), which was synthesized in close accordance to a procedure described in the literature [32], the corresponding divinyl and diallyl derivatives were synthesized (Scheme 1).

The vinyl-substituted compounds $\mathbf{2 a}$, $\mathbf{b}$ were prepared in an substitution/elimination reaction using BTE and 1,2-dibromoethane in analogy to described procedures for related divinyl bistetrazoles (Scheme 1a) [33]. The reaction gave a mixture of $2,2^{\prime}$ - and $1,2^{\prime}-N$ substituted compounds, 1,2-bis(2-vinyl-2H-tetrazol-5-yl)ethane (2a, 2,2-DvBTE) and 1-vinyl-5-(2-(2-vinyl-2H-tetrazol-5-yl)ethyl)- $1 H$-tetrazole (2b, 1,2-DvBTE). After purification via column chromatography $\mathbf{2 a}$ and $\mathbf{b}$ were obtained as colorless solids in low yields (31\% and 18\%). Recrystallization of $\mathbf{2 a}$ from an $n$-hexane-ethyl acetate mixture gave crystals suitable 
a)

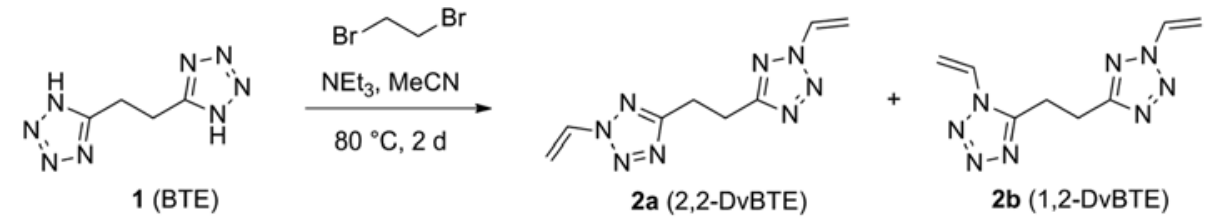

b)

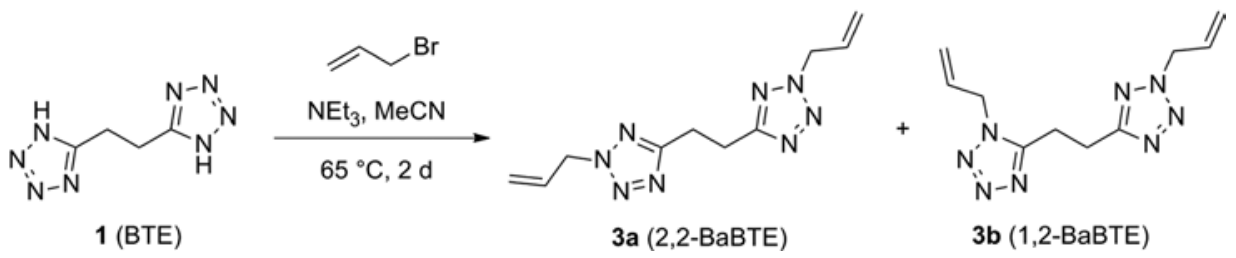

Scheme 1: Synthesis of the (a) divinyl (2a and $\mathbf{2 b}$ ) and (b) diallyl (3a and $\mathbf{3 b}$ ) derivatives of BTE (1).

for X-ray diffraction. The diallyl derivatives of BTE were obtained in a substitution reaction using allyl bromide (Scheme 1b). After the purification via column chromatography compounds 3a (1,2-bis(2-allyl-2H-tetrazol-5-yl) ethane, 2,2-BaBTE) and 3b (1-allyl-5-(2-(2-allyl-2H-tetrazol5-yl)ethyl)-1H-tetrazole, 1,2-BaBTE) were obtained as colorless liquids in low yields with $28 \%$ and $15 \%$, respectively.

\subsection{Spectroscopic analyses}

The synthesized compounds were characterized using elemental analysis, mass spectrometry, as well as ${ }^{1} \mathrm{H},{ }^{13} \mathrm{C}$ NMR and IR spectroscopy. The crystal structure of 2a was determined using single-crystal X-ray diffraction data.

[D $\mathrm{D}_{6}$ DMSO was used as solvent for the NMR measurements. BTE (1) gave consistent results with the literature values [32]. For a clear assignment of the exact positions of the carbon and hydrogen atoms in $\mathbf{3 a}$ and $\mathbf{3 b} 2 \mathrm{D}$ NMR measurements were carried out. The spectra of the HMQC and HMBC 2D NMR measurements are depicted in Figs. S1-S4 of the Supporting Information.

Both isomers of 3 can be distinguished by their signal patterns in the $1 \mathrm{D}{ }^{1} \mathrm{H}$ and ${ }^{13} \mathrm{C}$ NMR spectra (Figs. 1 and 2). In the ${ }^{1} \mathrm{H}$ NMR spectrum of $3 \mathbf{a}$ five different, partly overlapping signals can be observed at $6.04 \mathrm{ppm}$ ( $\mathrm{CH}$ of the allyl group), $5.29 \mathrm{ppm}\left(\mathrm{CH}_{\text {cis }}\right.$ of the terminal $\mathrm{CH}_{2}$ of the allyl group), $5.28 \mathrm{ppm}$ (aliphatic $\mathrm{CH}_{2}$ of the allyl group), $5.20 \mathrm{ppm}\left(\mathrm{CH}_{\text {trans }}\right.$ of the terminal $\mathrm{CH}_{2}$ of the allyl group) and $3.33 \mathrm{ppm}\left(\mathrm{CH}_{2}\right)$ in a 2:6:2:4 intensity ratio. The signals show different coupling patterns due to their different interactions with the surrounding hydrogen atoms. The $\mathrm{CH}$ of the allyl group shows a doublet of doublets of triplets assigned to its ${ }^{3} \mathrm{~J}_{\mathrm{HH}}$ couplings to the $\mathrm{CH}_{\text {trans }}$ and $\mathrm{CH}_{\text {cis }}$ of the terminal $\mathrm{CH}_{2}$ group and to the aliphatic $\mathrm{CH}_{2}$ group. The geminal hydrogen atoms of the terminal $\mathrm{CH}_{2}$ group also show a doublet of doublets of triplets splitting, representing the respective ${ }^{3} J_{\mathrm{HH}}$ (to the vinyl $\mathrm{CH}$ ), ${ }^{4} J_{\mathrm{HH}}$ (to the aliphatic $\mathrm{CH}_{2}$ ) and the ${ }^{2} J_{\mathrm{HH}}$ couplings. Both geminal hydrogen atoms can be distinguished because of their differing ${ }^{3} J_{\mathrm{HH}}$ coupling constants $\left(17.2 \mathrm{~Hz}\left(\mathrm{H}_{\text {trans }}\right)\right.$ and $\left.10.1 \mathrm{~Hz}\left(\mathrm{H}_{\text {cis }}\right)\right)$. The aliphatic $\mathrm{CH}_{2}$ group of the allyl group shows a doublet of doublets of doublets representing the respective couplings to the $\mathrm{CH}$ and the terminal $\mathrm{CH}_{2}$ hydrogen atoms.

The ${ }^{1} \mathrm{H}$ NMR spectrum of $\mathbf{3 b}$ shows 10 different overlapping signals (Fig. 1) with an intensity ratio of 2:5:3:4. The signal around $3.39 \mathrm{ppm}$ represents the two different $\mathrm{CH}_{2}$ groups attached to the respective $\mathrm{C}_{\mathrm{q}}$ of the tetrazole rings and shows an $\mathrm{A}_{2} \mathrm{~B}_{2}$ spin system of higher order. The signal is also overlapped by the signal of residual water, which explains the higher integral value.

A comparison of the ${ }^{13} \mathrm{C}$ NMR spectra of $\mathbf{3 a}$ and $\mathbf{b}$ (Fig. 2) also proves the existence of two isomers. Whereas the spectrum of 3a shows only five signals (as an indicator for symmetrically substituted tetrazole rings), $\mathbf{3 b}$ must be the asymmetric $1,2^{\prime}-N$-substituted isomer, because of its 10 signals. To determine, which kind of symmetrically $N$-substituted isomer was formed as $\mathbf{3 a}\left(1,1^{\prime}-\right.$ or $\left.2,2^{\prime}-\right)$, along with the general assignment of the proton and carbon positions in 3a and 3b, HMQC and HMBC 2D NMR measurements were the methods of choice (see Supporting Information, Figs. S1S4). Here, the 1- or the 2- $N$ substituted position can be distinguished by the occurring ${ }^{3} J_{\mathrm{CH}}$ long-range heteronuclear carbon-proton coupling between the quaternary carbon in the tetrazole ring and the protons of the aliphatic $\mathrm{CH}_{2}$ group attached to the N1 atom of the tetrazole ring (Fig. 3).

The HMBC experiments (Figs. S3 and S4) verified the $2,2^{\prime}-N$-substitution pattern for 3 a, as no ${ }^{3} J_{\mathrm{CH}}$ coupling between the $\mathrm{H} 4$ hydrogens and the $\mathrm{C} 1$ carbon atoms are visible in the 2D NMR spectrum. However, in the 2D HMBC spectrum of $\mathbf{3 b}$, the signal of the ${ }^{3} \mathrm{~J}_{\mathrm{CH}}$ coupling between 

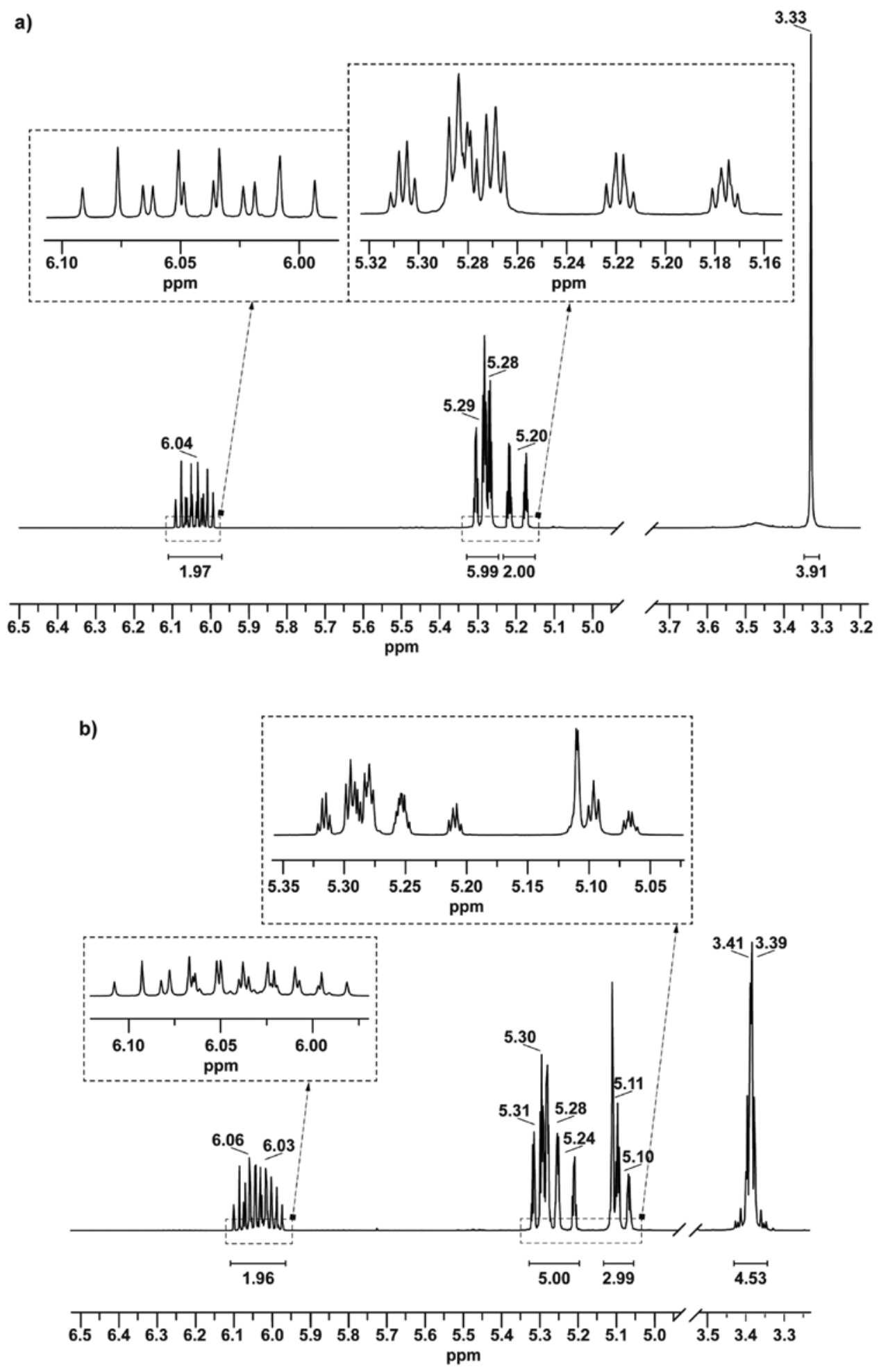

Fig. 1: ${ }^{1} \mathrm{H}$ NMR spectra of (a) $3 a$ and (b) $3 b$.

$\mathrm{C} 2$ and $\mathrm{H} 8$ is visible, which confirms the asymmetric $1,2^{\prime}$ - $N$-substituted structure.

For the assignment of the remaining carbon and hydrogen positions in $\mathbf{3} \mathbf{a}$ and $\mathbf{3} \mathbf{b}$ the HMQC measurements were beneficial (Figs. S1 and S2). The resulting spectra enabled the allocation of the carbon signals $\mathrm{C} 3$ and $\mathrm{C} 4$ of $\mathbf{3 b}$ to the overlapping signals of their corresponding protons $\mathrm{H} 3$ and $\mathrm{H} 4$. A precise distinction between the two 

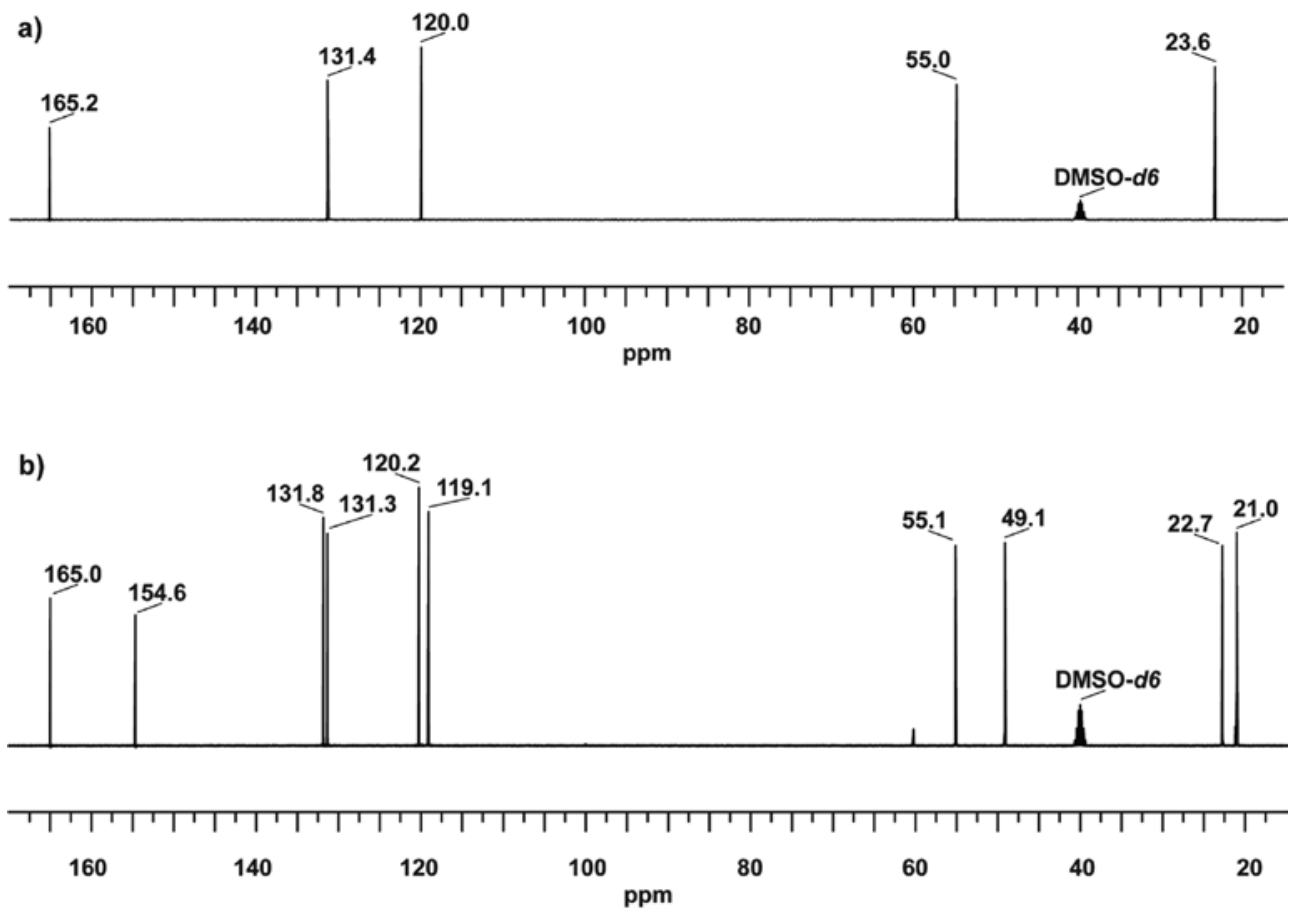

Fig. 2: ${ }^{13} \mathrm{C}$ NMR spectra of (a) 3a and (b) $3 \mathbf{b}$.

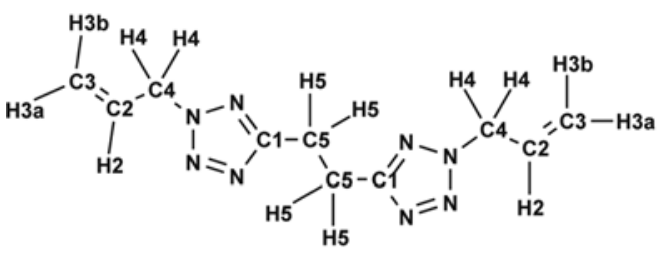

$3 a$

No ${ }^{3} \mathrm{~J}_{\mathrm{CH}}$ coupling

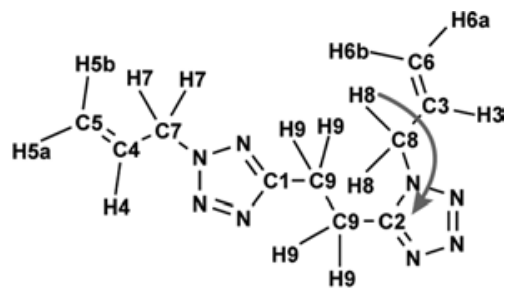

3b

${ }^{3} \mathrm{~J}_{\mathrm{CH}}$ coupling

Fig. 3: ${ }^{3} \mathrm{CH}_{\mathrm{C}}$ couplings for the differentiation between the 2- and 1- $\mathrm{N}$-substituted allyl positions.

different C9 carbon atoms and their corresponding H9 protons of $\mathbf{3 b}$ was not possible.

The ${ }^{1} \mathrm{H}$ spectrum of $\mathbf{2 a}$ shows four different signals with a 2:2:2:4 intensity ratio (Fig. 4). At $7.79 \mathrm{ppm}$ the $\mathrm{CH}$ of the vinyl group is visible as a doublet of doublets, representing the interactions with the geminal hydrogen atoms of the terminal $=\mathrm{CH}_{2}$. These two geminal hydrogen atoms of the vinyl group also show doublets of doublets as coupling patterns. The signal at $6.06 \mathrm{ppm}$ can be assigned to the $\mathrm{H}_{\text {trans }}$ of the terminal vinyl- $\mathrm{CH}_{2}$, because of its larger ${ }^{3} J_{\mathrm{HH}}$ coupling value $(15.5 \mathrm{~Hz})$ compared to the ${ }^{3} J_{\mathrm{HH}}$ coupling value $(8.7 \mathrm{~Hz})$ of the $\mathrm{H}_{\text {cis }}$ at $5.47 \mathrm{ppm}$. The protons of the aliphatic $\mathrm{CH}_{2}$ group occur at $3.41 \mathrm{ppm}$. Similar to the results of the measurement of $3 a$, the ${ }^{1} \mathrm{H}$ NMR spectrum of 3b shows eight different, partly overlapping signals with an intensity ratio of 1:1:1:1:2:4, representing the asymmetric $1,2^{\prime}-N$-substituted divinyl compound. The new signals of the $\mathrm{CH}$ and the $\mathrm{CH}_{\text {trans }}$ protons of the $1-\mathrm{N}$-substituted vinyl group can clearly be assigned at $7.47 \mathrm{ppm}$ and 5.97 ppm, whereas the signals of the two $\mathrm{CH}_{\text {cis }}$ protons are overlapping and cannot be allocated properly. The signal around $3.47 \mathrm{ppm}$ represents the two different $\mathrm{CH}_{2}$ groups attached to the respective $\mathrm{C}_{\mathrm{q}}$ of the tetrazole rings and shows an $\mathrm{A}_{2} \mathrm{~B}_{2}$ spin system of higher order.

The results of the 2D NMR measurements of $\mathbf{3 a}$ and $\mathbf{3 b}$ can be applied to assignments in the 1D NMR spectra of $\mathbf{2} \mathbf{a}$ and $\mathbf{2} \mathbf{b}$. Here again, the comparison of the ${ }^{13} \mathrm{C}$ NMR spectra of $\mathbf{2 a}$ and $\mathbf{b}$ (Fig. 5) proves the existence of two different isomers. Whereas the spectrum of 2a shows only four different signals (as indicators for 
a)

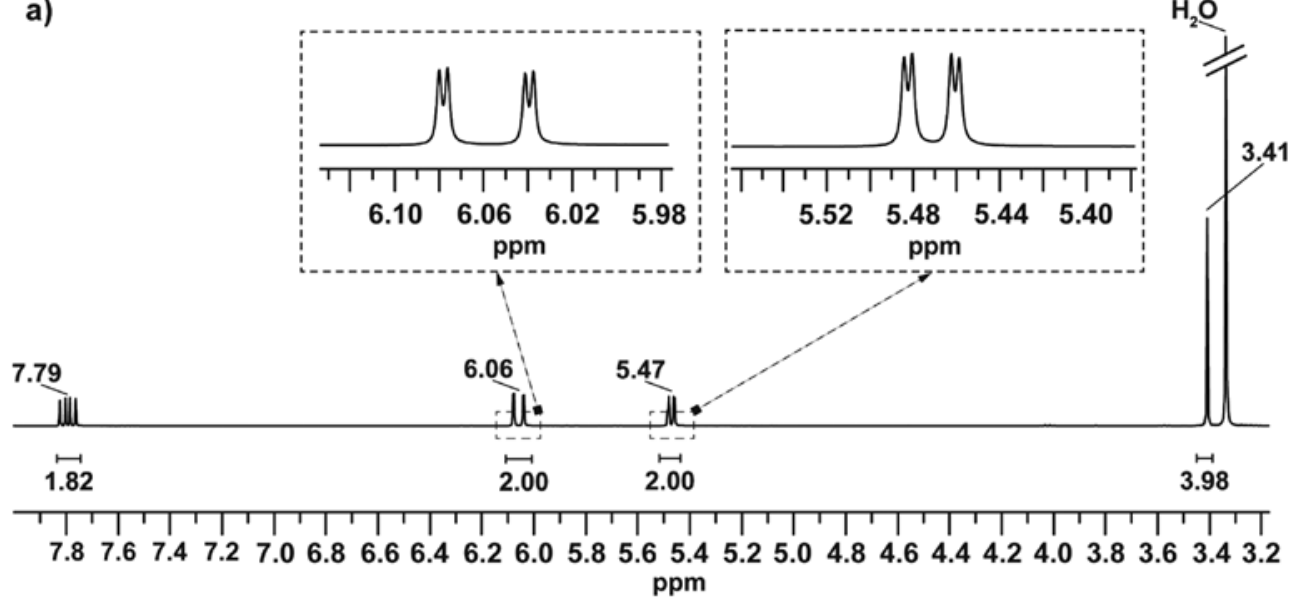

b)

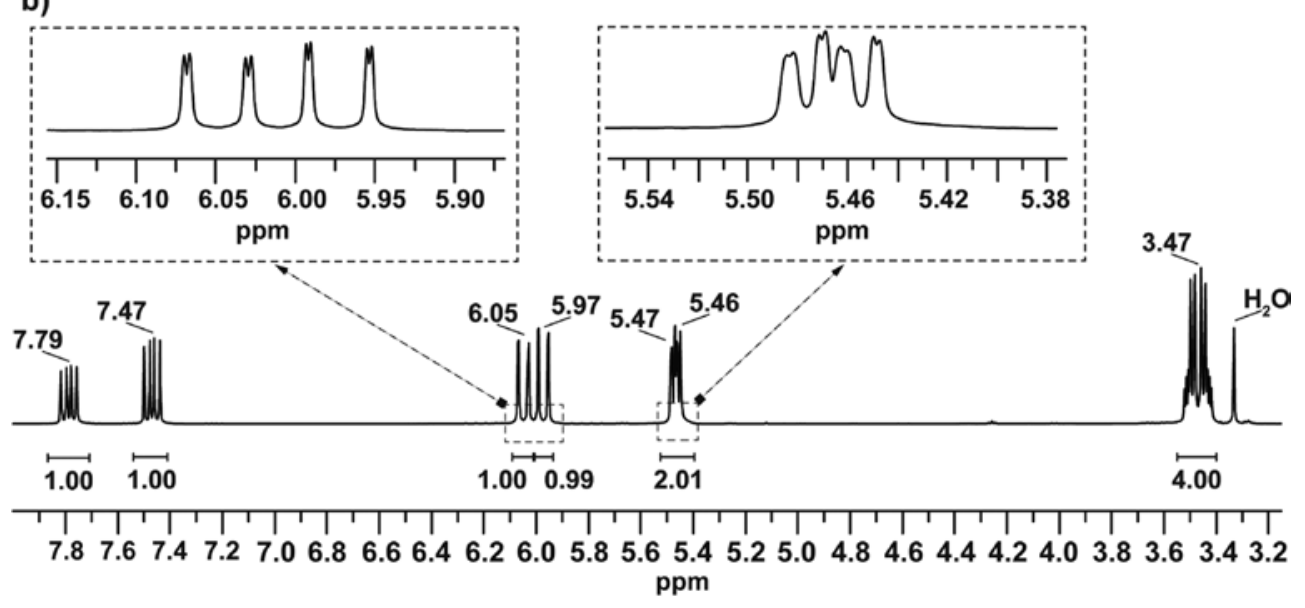

Fig. 4: ${ }^{1} \mathrm{H}$ NMR spectra of (a) $2 \mathrm{a}$ and (b) $2 \mathrm{~b}$.

symmetrically substituted tetrazole rings), $\mathbf{2} \mathbf{b}$ must be the asymmetric $1,2^{\prime}-N$-substituted isomer because of its eight different signals. In analogy to the diallyl compounds 3a and $\mathbf{b}, \mathbf{2 a}$ and $\mathbf{b}$ show signals at $164.9 \mathrm{ppm}$ $\left(\mathrm{C}_{\mathrm{q}}\right), 130.1 \mathrm{ppm}$ (CH vinyl), $109.0\left(\mathrm{CH}_{2}\right.$ vinyl) and around $22.9 \mathrm{ppm}$ (aliphatic $\mathrm{CH}_{2}$ ), which represent the 2- $\mathrm{N}$-substituted fragment. The additional signals in the ${ }^{13} \mathrm{C}$ NMR spectrum of $\mathbf{3 b}$ at 153.3, 126.5, 109.9 and $20.5 \mathrm{ppm}$ can be assigned in an analogous manner to the $1-\mathrm{N}$-substituted isomer.

\subsection{Structure determination by X-ray diffraction}

Single crystals suitable for X-ray diffraction were obtained by recrystallization from an $n$-hexane-ethyl acetate mixture.
A summary of crystallographic refinement parameters and structure data for $\mathbf{2 a}$ is given in Table 1 .

Compound 2a crystallizes in the monoclinic space group $P 2_{1} / c$ with two formula units per unit cell. Calculated density for $T=173 \mathrm{~K}$ is $1.414 \mathrm{~g} \mathrm{~cm}^{-3}$. The bond lengths and angles within the crystal structure of $\mathbf{2 a}$ are consistent with comparable values in the literature $[34,35]$. The formula unit of 2,2-DvBTE (2a) is shown in Fig. 6 along with selected bond lengths, angles and torsion angles. The molecular structure itself shows a slightly twisted assembly with a torsion angle of $110.8^{\circ}$ for the $\mathrm{C} 1^{\mathrm{i}}-\mathrm{C} 1-\mathrm{C} 2-$ $\mathrm{N} 2$ fragment. The vinyl group is nearly in one plane with the tetrazole ring with a torsion angle of the vinyl group towards the tetrazole ring of $4.0^{\circ}$.

Due to the lack of suitable donors no hydrogen bonds are observed in the crystal system to stabilize the supramolecular structure. As shown in Fig. 7, the crystal structure of $\mathbf{2 a}$ consists of stacks of alternately oriented 
a)
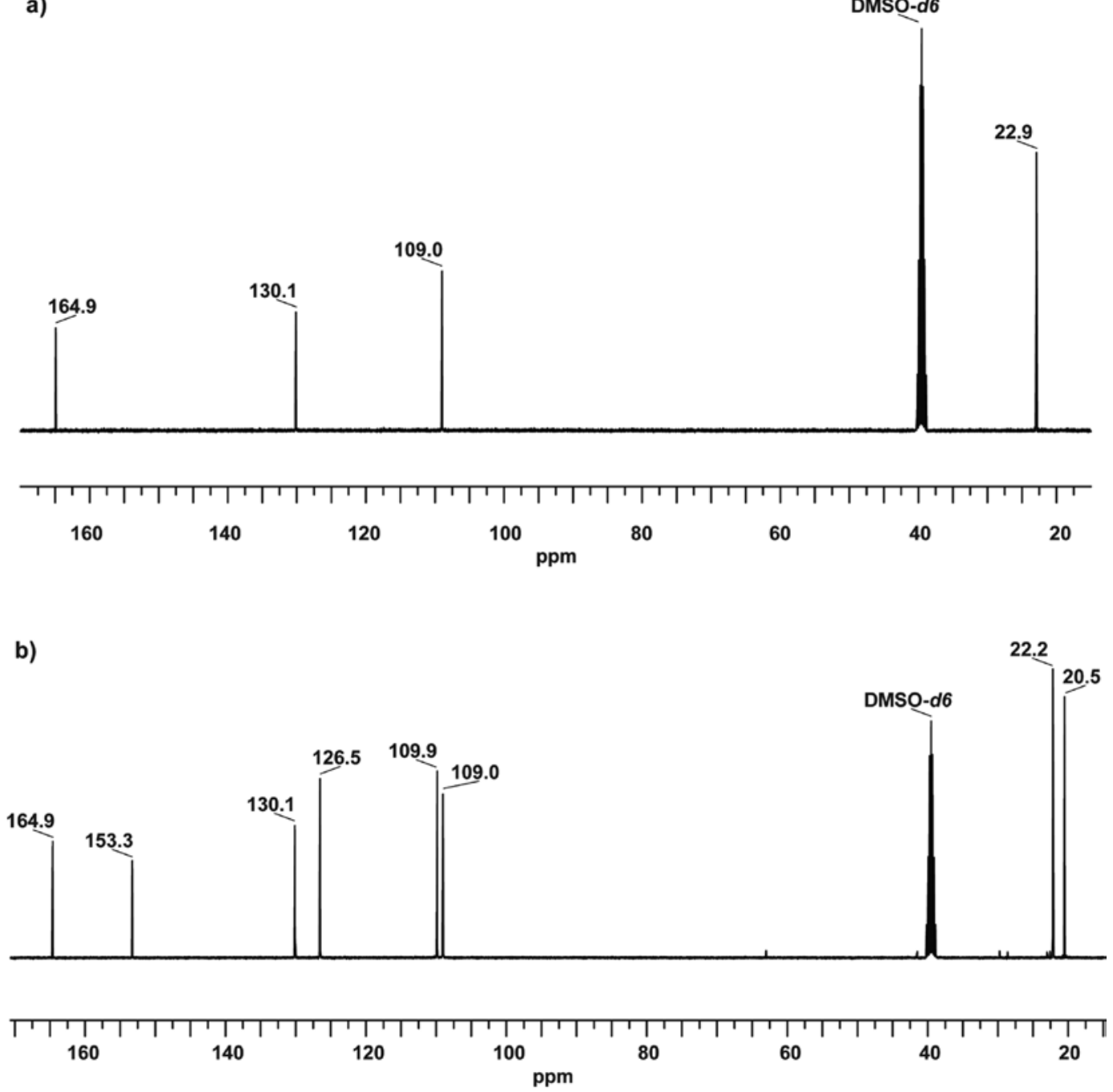

Fig. 5: ${ }^{13} \mathrm{C}$ NMR spectra of (a) $2 a$ and (b) $2 b$.

molecules which form infinite zig-zag rows along the crystallographic $a$ axis. The layers are stacked above each other.

\subsection{Thermal stability}

The behavior at high temperatures of compounds $\mathbf{2}-\mathbf{3}$ was determined via differential scanning calorimetry with a heating rate of $5^{\circ} \mathrm{C} \mathrm{min}^{-1}$. The obtained plots are depicted in Fig. 8.

The compounds containing the same functional groups show similar melting and decomposition temperatures. The vinyl-substitued compounds $\mathbf{2} \mathbf{a}$ and $\mathbf{2} \mathbf{b}$ show melting points around $90^{\circ} \mathrm{C}$ and decomposition temperatures around $190^{\circ} \mathrm{C}$, whereas the liquid allyl analogues $\mathbf{3} \mathbf{a}$ and $\mathbf{3 b}$ are stable up to higher temperatures with $T_{\text {dec }}$ around $230^{\circ} \mathrm{C}$.

\subsection{Energetic data}

To determine their inherent energetic potentials, sensitivities and energetic properties of compounds $\mathbf{2}-\mathbf{3}$ were investigated. The impact and friction sensitivities of $\mathbf{2 - 3}$ were explored by BAM methods [16-22]. All compounds were found as insensitive towards impact ( $>40 \mathrm{~J}$ ) and friction $(>360 \mathrm{~N})$.

For calculating the energetic properties of compounds 2-3 quantum chemical calculations were carried out. Initial structure optimizations for $\mathbf{2} \mathbf{b}$ and $\mathbf{3} \mathbf{a}, \mathbf{b}$ were performed at the B3LYP/cc-pVDZ level of theory using GaUSSIAN 09 (revision A.02) [36]. The enthalpies (H) and free energies (G) were calculated by the atomization method using electronic energies (CBS-4M method) $[37,38]$.

All calculations concerning the detonation parameters were carried out using the program package ExPLO5 
Table 1: Crystal and structure determination data for $\mathbf{2 a}$.

\begin{tabular}{|c|c|}
\hline Chemical formula & $\mathrm{C}_{8} \mathrm{H}_{10} \mathrm{~N}_{8}$ \\
\hline Molecular weight, $\mathrm{g} \mathrm{mol}^{-1}$ & 218.22 \\
\hline Color, habit & colorless block \\
\hline Size, $\mathrm{mm}^{3}$ & $0.07 \times 0.31 \times 0.51$ \\
\hline Crystal system & monoclinic \\
\hline Space group & $P 2_{1} / c$ \\
\hline$a, \AA$ & $9.137(4)$ \\
\hline$b, \AA$ & $8.166(4)$ \\
\hline$c, \AA$ & $6.941(4)$ \\
\hline$\beta$, deg & $98.164(5)$ \\
\hline$V, \AA^{3}$ & $512.61(4)$ \\
\hline$z$ & 2 \\
\hline$\rho_{\text {calcd }}, \mathrm{g} \mathrm{cm}^{-3}$ & 1.414 \\
\hline$\mu, \mathrm{mm}^{-1}$ & 0.10 \\
\hline $\mathrm{F}(000), e$ & 228 \\
\hline$\theta$ range, deg & $4.27-26.35$ \\
\hline$T, \mathrm{~K}$ & 173 \\
\hline Dataset $h$ & $-7 \leq h \leq 11$ \\
\hline Dataset $k$ & $-10 \leq k \leq 10$ \\
\hline Dataset $l$ & $-8 \leq l \leq 8$ \\
\hline Reflecions coll. & 3803 \\
\hline Independent refl. & 1049 \\
\hline Observed refl. & 930 \\
\hline$R_{\mathrm{int}}$ & 0.022 \\
\hline Ref. parameters & 94 \\
\hline$R 1^{\mathrm{a}} / w R 2^{\mathrm{b}}(2 \sigma$ data $)$ & $0.0302 / 0.0698$ \\
\hline$R 1^{\mathrm{a}} / w R 2^{\mathrm{b}}$ (all data) & $0.0351 / 0.0739$ \\
\hline Weighting scheme $A / B^{b}$ & $0.0292 / 0.1084$ \\
\hline $\mathrm{GoF}^{\mathrm{c}}$ & 1.085 \\
\hline Residual density $\max / \min , e \AA^{-3}$ & $-0.148 / 0.191$ \\
\hline
\end{tabular}

${ }^{\mathrm{a}} R 1=\Sigma|| F_{0}|-| F_{\mathrm{c}}|| / \Sigma\left|F_{0}\right| ;{ }^{\mathrm{b}} W R 2=\left[\Sigma w\left(F_{0}^{2}-F_{\mathrm{c}}^{2}\right)^{2} / \Sigma w\left(F_{0}^{2}\right)^{2}\right]^{1 / 2}$, $w=\left[\sigma^{2}\left(F_{0}^{2}\right)+(\mathrm{A} P)^{2}+\mathrm{BP}\right]^{-1}$, where $P=\left(\operatorname{Max}\left(F_{0}^{2}, 0\right)+2 F_{\mathrm{c}}^{2}\right) / 3$; ${ }^{\mathrm{c}} \mathrm{GoF}=S=\left[\Sigma w\left(F_{\mathrm{o}}^{2}-F_{\mathrm{c}}^{2}\right)^{2} /\left(n_{\mathrm{obs}}-n_{\text {param }}\right)\right]^{1 / 2}$.

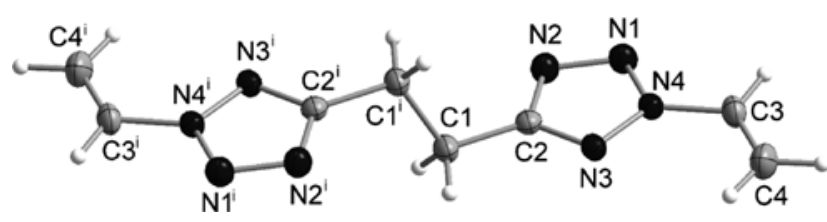

Fig. 6: Molecular structure of 2,2-DvBTE (2a) in the crystal. Displacement ellipsoids are at the $50 \%$ probability level, $\mathrm{H}$ atoms are drawn as spheres with arbitrary radii. Symmetry operator: (i) $-x$, $2-y,-z$. Selected bond lengths ( $\AA$ ): N1-N2 1.316(1), N1-N4 1.327(1), N2-C2 1.353(1), N3-C2 1.327(1), N3-N4 1.336(1), N4-C3 1.419(1), C1-C2 1.487(2), C3-C4 1.304(2); selected bond angles (deg): C1-C1-C2 112.1(1), C4-C3-N4 123.0(1); selected torsion angles (deg): C1'-C1-C2-N2 110.8, C1'-C1-C2-N3-67.6(1), C4-C3-N4-N1 $-175.3(1)$, C4-C3-N4-N3 4.0(2).

(version 6.02) [39, 40] and were based on the calculated solid and liquid state heats of formation and attributed to the corresponding densities. For a discussion of the methods that were used for calculations, see the Supporting Information. The calculated detonation values of compounds 2-3 are given in Table 2.

The obtained detonation values show moderate energetic properties for 2-3. Due to their higher $\Delta_{\mathrm{f}} H_{\mathrm{m}}{ }^{\circ}$ value and density, as well as lower carbon content, vinyl based 2a and $\mathbf{2 b}$ show an about $1000 \mathrm{~m} \mathrm{~s}^{-1}$ increased detonation velocity $\left(V_{\text {det }}\right)$ and an about 50 kbar higher detonation pressure $\left(p_{\mathrm{CJ}}\right)$, when compared to the respective allyl based isomers $\mathbf{3 a}$ and $\mathbf{3 b}$. A comparison of the corresponding isomers, in relation to each other, revealed slightly increased detonation values for the unsymmetrically substituted compounds, due to their higher enthalpy of formation.

\section{Conclusion}

In the course of our work aimed at generating suitable precursors for further (polymeric) processing, divinyl and diallyl derivatives of 1,2-bis(tetrazol-5-yl)ethane were synthesized and characterized. Two different constitutional isomers of each compound were isolated. The thermal behavior, as well as the sensitivities and energetic properties of the compounds were investigated. The compounds were found to be stable up to $190^{\circ} \mathrm{C}$ and $230^{\circ} \mathrm{C}$, respectively, and insensitive towards impact and friction. Due to the dual terminal double bonds present in the compounds, they offer possibilities for diverse processing steps.

\section{Experimental section}

All chemical reagents and solvents of analytical grade were obtained from Sigma-Aldrich, Acros Organics or $\mathrm{ABCR}$ and used without further purification. BTE was synthesized in close accordance to a procedure described in the literature [32].

Purification by column chromatography was performed using Merck silica gel $60(\emptyset 35-70 \mu \mathrm{m})$. The eluent is given in the respective compound section. ${ }^{1} \mathrm{H}$, ${ }^{13} \mathrm{C}$ and 2D NMR spectra were recorded with a JEOL 400 or a Bruker 400 (TR) instrument. The spectra were measured at $25^{\circ} \mathrm{C}$. The chemical shifts are given relative to tetramethylsilane as external standard. Infrared spectra were measured with a Perkin-Elmer Spectrum BX-FTIR spectrometer equipped with a Smiths DuraSamplIR II ATR device. All spectra were recorded at ambient 


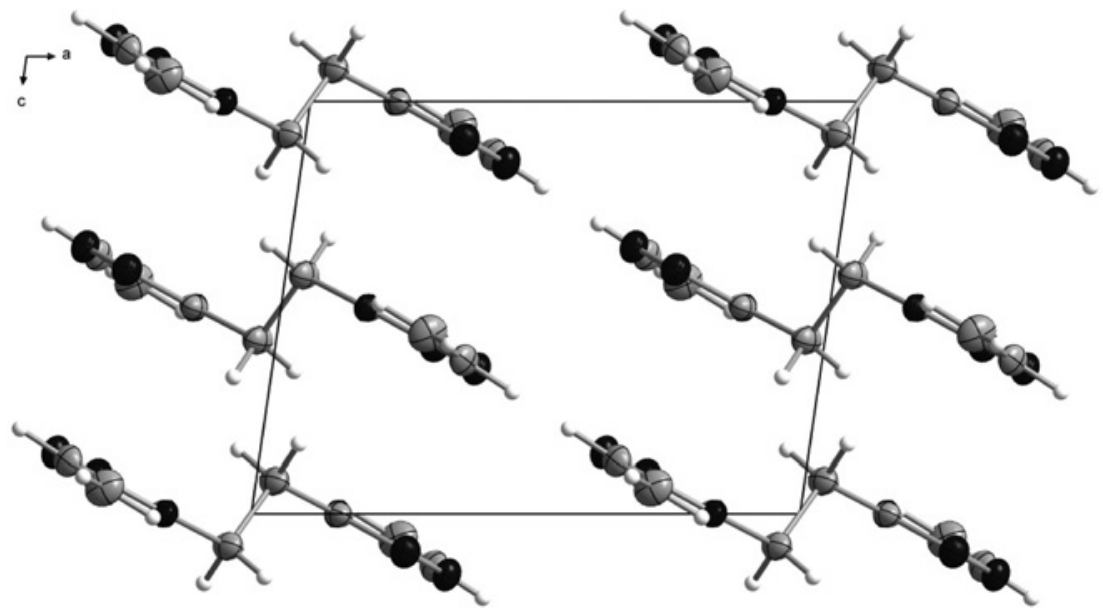

Fig. 7: View of the crystal structure of 2 a along the crystallographic $b$ axis. Displacement ellipsoids are at the $50 \%$ probability level, $\mathrm{H}$ atoms are drawn as spheres with arbitrary radii.

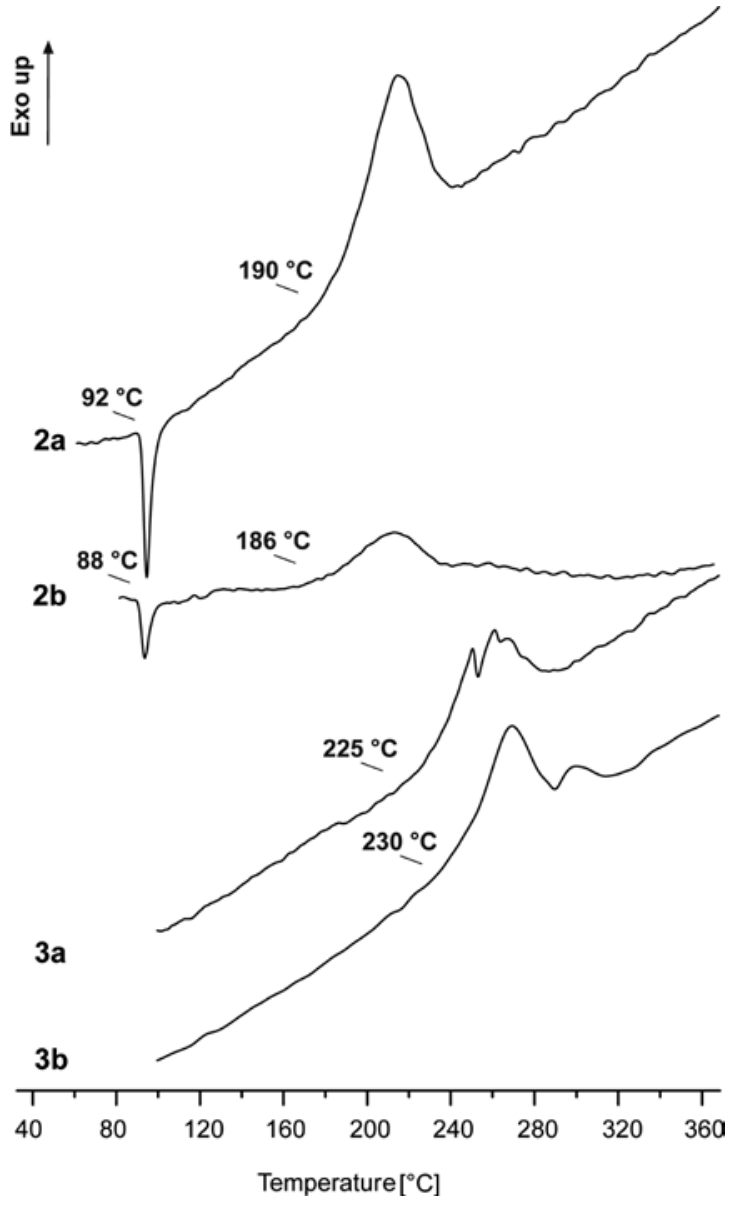

Fig. 8: DSC plots of the decomposition temperature of compounds $2-3$, in the temperature range $40-360^{\circ} \mathrm{C}$ (exothermal up).

temperature; all samples were neat liquids or solids. Elemental analysis $(\mathrm{C} / \mathrm{H} / \mathrm{N})$ was performed with an Elementar Vario EL analyzer.
Table 2: Energetic data of the divinyl and diallyl compounds 2a, b and $\mathbf{3 a}, \mathbf{b}$.

\begin{tabular}{|c|c|c|c|c|}
\hline & $2 a$ & $2 b$ & $3 a$ & $3 b$ \\
\hline Formula & $\mathrm{C}_{8} \mathrm{H}_{10} \mathrm{~N}_{8}$ & $\mathrm{C}_{8} \mathrm{H}_{10} \mathrm{~N}_{8}$ & $\mathrm{C}_{10} \mathrm{H}_{14} \mathrm{~N}_{8}$ & $\begin{array}{l}\mathrm{C}_{10} \mathrm{H}_{14} \mathrm{~N}_{8} \\
246.27\end{array}$ \\
\hline $\mathrm{FW}, \mathrm{g} \mathrm{mol}^{-1}$ & 218.22 & 218.22 & & \\
\hline IS, J $\mathrm{J}^{\mathrm{a}}$ & $>40$ & $>40$ & $>40$ & $>40$ \\
\hline $\mathrm{FS}, \mathrm{N}^{\mathrm{b}}$ & $>360$ & $>360$ & $>360$ & $>360$ \\
\hline$N, \%^{c}$ & 51.35 & 51.35 & 45.50 & 45.50 \\
\hline$T_{\text {Dec }},{ }^{\circ} \mathrm{C}^{\mathrm{d}}$ & 190 & 186 & 225 & 230 \\
\hline$\rho, \mathrm{g} \mathrm{cm}^{-3 \mathrm{e}}$ & 1.4 & 1.4 & 1.2 & 1.2 \\
\hline$\Delta_{\mathrm{f}} H_{\mathrm{m}}{ }^{\circ}, \mathrm{kJ} \mathrm{mol}^{-1 \mathrm{f}}$ & 635 & 643 & 605 & 622 \\
\hline$\Delta_{\mathrm{f}} U^{\circ}, \mathrm{kJ} \mathrm{kg}^{-1 \mathrm{~g}}$ & 2907 & 2970 & 2452 & 2504 \\
\hline \multicolumn{5}{|c|}{ EXPL05 V6.02 values } \\
\hline$-\Delta_{\mathrm{E}} U^{\circ}, \mathrm{kJ} \mathrm{kg}^{-1 \mathrm{~h}}$ & 3681 & 3743 & 3398 & 3448 \\
\hline$T, \mathrm{~K}^{\mathrm{i}}$ & 2317 & 2341 & 2131 & 2150 \\
\hline$p_{\mathrm{cl}}, \mathrm{kbar}^{\mathrm{j}}$ & 148 & 149 & 99 & 99 \\
\hline$V_{\text {Det }}, \mathrm{m} \mathrm{s}^{-1 \mathrm{k}}$ & 7109 & 7132 & 6148 & 6167 \\
\hline Gas vol., $\mathrm{L} \mathrm{kg}^{-1 \mathrm{l}}$ & 702 & 703 & 737 & 737 \\
\hline$I_{s}, s^{m}$ & 197 & 198 & 188 & 189 \\
\hline
\end{tabular}

aBAM drop hammer (1 of 6); ${ }^{\text {b} B A M ~ f r i c t i o n ~ t e s t e r ~(1 ~ o f ~ 6) ; ~ ' ~}$ nitrogen

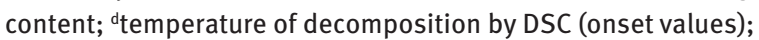
ederived from pycnometer measurements; ${ }^{\text {fmolar }}$ enthalpy of formation; senergy of formation; henergy of explosion; 'explosion temperature; 'detonation pressure; 'detonation velocity; 'assuming only gaseous products; ${ }^{\mathrm{m}}$ specific impulse (isobaric combustion, chamber pressure 70 bar, equilibrium expansion).

Decomposition temperatures were determined by differential scanning calorimetry (DSC) with a Linseis DSC PT10 calibrated by standard pure indium and zinc, using a heating rate of $5^{\circ} \mathrm{C} \mathrm{min}^{-1}$ in covered aluminum pans and a nitrogen flow of $20 \mathrm{~mL} \mathrm{~min}{ }^{-1}$. Pycnometric measurements were carried out with a Quantachrome Ultrapyc $1200 e$ pycnometer. High resolution measurements were recorded on a Finnigan MAT 95 instrument. Impact and 
friction sensitivity tests were carried out according to STANAG 4489 and STANAG 4487 modified instructions using a BAM (Bundesanstalt für Materialforschung) drop hammer and friction tester [16-22]. The classification of the tested compounds results from the "UN Recommendations on the Transport of Dangerous Goods".

\subsection{1,2-Bis(2-vinyl-2H-tetrazol-5-yl)ethane (2,2-DvBTE, 2a) and 1-(2-vinyl-2H- tetrazol-5-yl)-2-(1-vinyl-1H-tetrazol-5-yl) ethane (1,2-DvBTE, 2b)}

1,2-Dibromoethane $(8.3 \mathrm{~mL}, 96 \mathrm{mmol})$ was dissolved in acetonitrile $(30 \mathrm{~mL})$ and heated to $80^{\circ} \mathrm{C}$. BTE $(\mathbf{1 2}, 4.00$ $\mathrm{g}, 24.08 \mathrm{mmol})$ was dissolved in acetonitrile $(20 \mathrm{~mL})$ and triethylamine ( $8.3 \mathrm{~mL}, 96 \mathrm{mmol})$. This mixture was added into the reaction flask over $5 \mathrm{~h}$ using a dropping funnel. Stirring at $80^{\circ} \mathrm{C}$ was continued for 2 days. After cooling to ambient temperature, brine $(50 \mathrm{~mL})$ was added and the aqueous phase was extracted with ethyl acetate $(3 \times 100 \mathrm{~mL})$. The combined organic phases were dried over $\mathrm{MgSO}_{4}$ and the volatiles were removed in vacuo. The crude product was purified using column chromatography on silica gel (eluent: $n$-hexane-DCM-EtOAc $=5: 3: 2$ ).

\subsection{1,2-Bis(2-vinyl-2H-tetrazol-5-yl)ethane (2,2-DvBTE, 2a)}

Compound 2a was obtained as a colorless solid in 31\% yield (1.63 g, $\left.7.46 \mathrm{mmol}, R_{\mathrm{f}}=0.6\right)$ and was recrystallized from a $n$-hexane-ethyl acetate mixture.

M. p. $92^{\circ} \mathrm{C} .-$ dec. $190^{\circ} \mathrm{C} .-\mathrm{IR}\left(\mathrm{ATR}, \mathrm{cm}^{-1}\right): \hat{v}=3119(\mathrm{w})$, 3108 (w), 3060 (w), 3010 (w), 2988 (w), 2399 (w), 1919 (w), 1842 (w), 1738 (w), 1694 (w), 1643 (m), 1509 (s), 1480 (w), 1442 (w), 1408 (w), 1384 (m), 1353 (m), 1290 (w), 1263 (w), 1233 (m), 1182 (s), 1130 (w), 1078 (w), 1031 (m), 1006 (s), 961 (s), 914 (vs), 776 (w), 757 (s), 740 (s), 730 (s). $-{ }^{1} \mathrm{H}$ NMR (400 MHz, [D $\mathrm{D}_{6} \mathrm{DMSO}, 25^{\circ} \mathrm{C}$, TMS): $\delta=7.79\left(\mathrm{dd},{ }^{3} J_{\mathrm{HH}}=15.5\right.$ $\left.\mathrm{Hz}, 8.7 \mathrm{~Hz}, 2 \mathrm{H},-\mathrm{CH}=\mathrm{CH}_{2}\right), 6.06\left(\mathrm{dd},{ }^{3} J_{\mathrm{HH}}=15.5 \mathrm{~Hz},{ }^{2} J_{\mathrm{HH}}=1.5\right.$ $\left.\mathrm{Hz}, 2 \mathrm{H}, \mathrm{CH}=\mathrm{CH} H_{\text {trans }}\right), 5.48\left(\mathrm{dd},{ }^{3} J_{\mathrm{HH}}=8.7 \mathrm{~Hz},{ }^{2} J_{\mathrm{HH}}=1.5 \mathrm{~Hz}\right.$, $\left.2 \mathrm{H}, \mathrm{CH}=\mathrm{CH} H_{\text {cis }}\right), 3.42\left(\mathrm{~s}, 4 \mathrm{H}, \mathrm{CH}_{2}-\mathrm{C}_{\text {tetrazole }}\right) .-{ }^{13} \mathrm{C}$ NMR (101 $\left.\mathrm{MHz},\left[\mathrm{D}_{6}\right] \mathrm{DMSO}\right): \delta=164.9\left(\mathrm{C}_{\text {tetrazole }}\right), 130.1 \quad\left(-\mathrm{CH}=\mathrm{CH}_{2}\right)$, $109.0\left(\mathrm{CH}=\mathrm{CH}_{2}\right), 22.9\left(\mathrm{CH}_{2}-\mathrm{C}_{\text {tetrazole }}\right)$. - HRMS ((+)-ESI): $m / z=219.1100$ (calcd. 219.1101 for $\mathrm{C}_{8} \mathrm{H}_{11} \mathrm{~N}_{8},[\mathrm{M}+\mathrm{H}]^{+}$). $\mathrm{C}_{8} \mathrm{H}_{10} \mathrm{~N}_{8}$ (218.22): calcd. C 44.03, H 4.62, $\mathrm{N}$ 51.24; found C 44.10, H 4.68, N 51.24.

\subsection{1-(2-Vinyl-2H-tetrazol-5-yl)-2-(1-vinyl-1H- tetrazol-5-yl)ethane (1,2-DvBTE, 2b)}

Compound $\mathbf{2 b}$ was obtained as a colorless solid in $18 \%$ yield (0.95 g, $\left.4.33 \mathrm{mmol}, R_{\mathrm{f}}=0.2\right)$.

M. p. $88^{\circ} \mathrm{C} .-\operatorname{dec} .186^{\circ} \mathrm{C} .-\operatorname{IR}\left(\operatorname{ATR}, \mathrm{cm}^{-1}\right): \hat{v}=3100(\mathrm{w})$, 2988 (w), 1743 (w), 1647 (m), 1501 (m), 1437 (m), 1410 (m), $1378(\mathrm{~m}), 1342(\mathrm{w}), 1291(\mathrm{w}), 1258(\mathrm{~m}), 1181(\mathrm{~m}), 1127(\mathrm{~m})$, 1087 (s), 1013 (vs), 950 (s), 919 (m), 792 (m), 726 (w), 700 (w). - ${ }^{1} \mathrm{H}$ NMR (400 MHz, [D 6 DMSO, $25^{\circ} \mathrm{C}, \mathrm{TMS}$ ): $\delta=7.79$ (dd, ${ }^{3} J_{\mathrm{HH}}=15.5 \mathrm{~Hz}, 8.7 \mathrm{~Hz}, 2 \mathrm{H}, \mathrm{N2}{ }^{\prime}-\mathrm{CH}=\mathrm{CH}_{2}$ ), 7.47 (dd, $\left.{ }^{3} J_{\mathrm{HH}}=15.3 \mathrm{~Hz}, 8.7 \mathrm{~Hz}, 1 \mathrm{H}, \mathrm{N} 1-\mathrm{CH}=\mathrm{CH}_{2}\right), 6.05\left(\mathrm{dd},{ }^{3} \mathrm{H}_{\mathrm{HH}}=15.5\right.$ $\left.\mathrm{Hz},{ }^{2} J_{\mathrm{HH}}=1.1 \mathrm{~Hz}, 1 \mathrm{H}, \mathrm{N} 2^{\prime}-\mathrm{CH}=\mathrm{CH} H_{\text {trans }}\right), 5.97\left(\mathrm{dd},{ }^{3} J_{\mathrm{HH}}=15.3\right.$ $\left.\mathrm{Hz},{ }^{2} \mathrm{H}_{\mathrm{HH}}=1.1 \mathrm{~Hz}, 1 \mathrm{H}, \mathrm{N} 1-\mathrm{CH}=\mathrm{CH} H_{\text {trans }}\right), 5.47\left(\mathrm{dd},{ }^{3} J_{\mathrm{HH}}=8.7\right.$ $\left.\mathrm{Hz},{ }^{2} \mathrm{~J}_{\mathrm{HH}}=1.1 \mathrm{~Hz}, 1 \mathrm{H}, \mathrm{CH}=\mathrm{CH} H_{\mathrm{cis}}\right), 5.46\left(\mathrm{dd},{ }^{3} J_{\mathrm{HH}}=8.7 \mathrm{~Hz}\right.$, $\left.{ }^{2} J_{\mathrm{HH}}=1.1 \mathrm{~Hz}, 1 \mathrm{H}, \mathrm{CH}=\mathrm{CHH}{ }_{\text {cis }}\right), 3.47\left(\mathrm{~m}, 4 \mathrm{H}, \mathrm{CH}_{2}-\mathrm{C}_{\text {tetrazole }}\right) .{ }^{13} \mathrm{C}$ NMR (101 MHz, [D $]$ DMSO): $\delta=164.9\left(C_{\mathrm{q}, \text { tetrazole }}-\mathrm{N} 1^{\prime}-\mathrm{N} 2^{\prime}-\right.$ $\mathrm{CH}=), 153.3\left(C_{\text {q, tetrazole }}-\mathrm{N} 1-\mathrm{CH}=\right), 130.1\left(\mathrm{~N} 2^{\prime}-\mathrm{CH}=\mathrm{CH}_{2}\right), 126.5$ $\left(\mathrm{N} 1-\mathrm{CH}=\mathrm{CH}_{2}\right), 109.9\left(\mathrm{~N} 1-\mathrm{CH}=\mathrm{CH}_{2}\right), 109.0\left(\mathrm{~N} 2^{\prime}-\mathrm{CH}=\mathrm{CH}_{2}\right)$, $22.2\left(\mathrm{CH}_{2}-\mathrm{C}_{\text {tetrazole }}\right), 20.5\left(\mathrm{CH}_{2}-\mathrm{C}_{\text {tetrazole }}\right) .-\mathrm{C}_{8} \mathrm{H}_{10} \mathrm{~N}_{8}$ (218.22): calcd. C 44.03, H 4.62, N 51.24; found C 44.12, H 4.59, N 51.20 .

\subsection{1,2-Bis(2-allyl-2H-tetrazol-5-yl)ethane (2,2-BaBTE, 3a) and 1-(2-allyl-2H-tetra- zol-5-yl)-2-(1-vinyl-1H-tetrazol-5-yl) ethane (1,2-BaBTE, 3b)}

Allyl bromide ( $4.8 \mathrm{~mL}, 55 \mathrm{mmol}$ ) was dissolved in acetonitrile $(20 \mathrm{~mL})$ and heated to $55^{\circ} \mathrm{C}$. BTE $(\mathbf{1}, 4.00 \mathrm{~g}, 24.08$ $\mathrm{mmol})$ was dissolved in acetonitrile $(20 \mathrm{~mL})$ and triethylamine ( $7.7 \mathrm{~mL}, 55 \mathrm{mmol})$. This mixture was added into the reaction flask over $5 \mathrm{~h}$ using a dropping funnel. Stirring at $65^{\circ} \mathrm{C}$ was continued for 2 days. Brine $(50 \mathrm{~mL})$ was added and the aqueous phase was extracted with ethyl acetate $(3 \times 100 \mathrm{~mL})$. The combined organic phases were dried over $\mathrm{MgSO}_{4}$ and the volatiles were removed in vacuo. The crude product was purified using column chromatography on silica gel (eluent: $n$-hexane-DCM-EtOAc $=5: 3: 2$ ).

\subsection{1,2-Bis(2-allyl-2H-tetrazol-5-yl)ethane (2,2-BaBTE, 3a)}

Compound 3a was obtained as yellowish liquid in $28 \%$ yield (1.71 mg, $\left.6.94 \mathrm{mmol}, R_{\mathrm{f}}=0.4\right)$.

Dec. $225^{\circ} \mathrm{C} .-$ IR (ATR, $\left.\mathrm{cm}^{-1}\right): \hat{v}=3090(\mathrm{w}), 2934(\mathrm{w})$, 1730 (m), 1648 (w), 1495 (s), 1424 (m), 1400 (m), 1375 (w), 
1336 (m), 1292 (w), 1260 (w), 1203 (m), 1174 (m), 1077 (m), 1028 (m), 989 (s), 936 (s), 921 (s), 795 (s), 710 (w), 673 (w). $-{ }^{1} \mathrm{H}$ NMR (400 MHz, [D] DMSO, $\left.25^{\circ} \mathrm{C}, \mathrm{TMS}\right): \delta=6.04$ (ddt, ${ }^{3} J_{\mathrm{HH}}=17.2,10.1,5.9 \mathrm{~Hz}, 2 \mathrm{H},-\mathrm{CH}=\mathrm{CH}_{2}$ ), 5.29 (ddt, $\left.{ }^{4} J_{\mathrm{HH}}=1.3 \mathrm{~Hz},{ }^{3} J_{\mathrm{HH}}=10.1 \mathrm{~Hz},{ }^{2} \mathrm{~J}_{\mathrm{HH}}=1.2 \mathrm{~Hz}, 2 \mathrm{H}, \mathrm{CH}=\mathrm{CH} H_{\mathrm{cis}}\right), 5.28$ (ddd, ${ }^{4} J_{\mathrm{HH}}=1.6,1.3 \mathrm{~Hz},{ }^{3} \mathrm{~J}_{\mathrm{HH}}=5.9 \mathrm{~Hz}, 4 \mathrm{H}, \mathrm{CH}_{2}-\mathrm{N}$ ), 5.20 (ddt, ${ }^{4} J_{\mathrm{HH}}=1.6 \mathrm{~Hz},{ }^{3} J_{\mathrm{HH}}=17.2 \mathrm{~Hz},{ }^{2} J_{\mathrm{HH}}=1.2 \mathrm{~Hz}, 2 \mathrm{H}, \mathrm{CH}=\mathrm{CH} H_{\text {trans }}$ ), 3.33 (s, 4H, $\left.\mathrm{CH}_{2}-\mathrm{C}_{\text {q,tetrazole }}\right) .-{ }^{13} \mathrm{C}$ NMR (101 MHz, [D $]$ ]DMSO): $\delta=165.2\left(C_{\text {q,tetrazole }}\right), 131.4 \quad\left(-\mathrm{CH}=\mathrm{CH}_{2}\right), 120.0 \quad\left(\mathrm{CH}=\mathrm{CH}_{2}\right)$, $55.0\left(\mathrm{CH}_{2}-\mathrm{N}\right), 23.6\left(\mathrm{CH}_{2}-\mathrm{C}_{\mathrm{q}, \text { tetrazole }}\right)$ - HRMS ((+)-ESI): $m / z=247.1412$ (calcd. 247.1414 for $\mathrm{C}_{10} \mathrm{H}_{15} \mathrm{~N}_{8},[\mathrm{M}+\mathrm{H}]^{+}$). $\mathrm{C}_{10} \mathrm{H}_{14} \mathrm{~N}_{8}$ (246.27): calcd. C 48.77, $\mathrm{H}$ 5.73, N 45.50; found C 48.46, H 5.44, N 45.13.

\subsection{1-(2-Allyl-2H-tetrazol-5-yl)-2-(1-vinyl-1H- tetrazol-5-yl)ethane (1,2-BaBTE, 3b)}

Compound 3b was obtained as a yellowish liquid in 15\% yield (0.89 g, $\left.3.71 \mathrm{mmol}, R_{\mathrm{f}}=0.2\right)$.

Dec. $230^{\circ} \mathrm{C}$. - IR (ATR, $\left.\mathrm{cm}^{-1}\right): \hat{v}=3089(\mathrm{w}), 2940(\mathrm{w})$, 1647 (w), 1522 (m), 1498 (s), 1459 (m), 1420 (s), 1336 (m), 1292 (w), 1249 (m), 1199 (w), 1172 (w), 1177 (w), 1083 (m), 1030 (m), 989 (vs), 924 (vs), 849 (m), 791 (s), 703 (w), $670(\mathrm{w}) .-{ }^{1} \mathrm{H}$ NMR (400 MHz, [D $]$ DMSO, $\left.25^{\circ} \mathrm{C}, \mathrm{TMS}\right):$ $\delta=6.06\left(\mathrm{~m}, 1 \mathrm{H}, \mathrm{N}^{\prime}-\mathrm{CH}_{2}-\mathrm{CH}=\mathrm{CH}_{2}\right), 6.03\left(\mathrm{~m}, 1 \mathrm{H}, \mathrm{N} 1-\mathrm{CH}_{2}-\right.$ $\left.\mathrm{CH}=\mathrm{CH}_{2}\right), 5.31\left(\mathrm{~m}, 1 \mathrm{H}, \mathrm{N}^{\prime}-\mathrm{CH}_{2}-\mathrm{CH}=\mathrm{CHH}_{\text {cis }}\right), 5.30(\mathrm{~m}, 2 \mathrm{H}$, $\left.\mathrm{N}^{\prime}-\mathrm{CH}_{2}\right), 5.28\left(\mathrm{~m}, 1 \mathrm{H}, \mathrm{N} 1-\mathrm{CH}_{2}-\mathrm{CH}=\mathrm{CHH}_{\text {cis }}\right), 5.24(\mathrm{~m}, 1 \mathrm{H}$, $\left.\mathrm{N}^{\prime}-\mathrm{CH}_{2}-\mathrm{CH}=\mathrm{CHH}_{\text {trans }}\right)$, 5.11. (m, 2H, N1- $\left.\mathrm{CH}_{2}\right), 5.10$ (m, $\left.1 \mathrm{H}, \mathrm{N} 1-\mathrm{CH}_{2}-\mathrm{CH}=\mathrm{CHH}_{\text {trans }}\right), 3.41\left(\mathrm{~m}, 2 \mathrm{H}, \mathrm{CH}_{2}-\mathrm{C}_{\text {q,tetrazole }}\right), 3.39$ (m, 2H, $\left.\mathrm{CH}_{2}-\mathrm{C}_{\mathrm{q} \text {,tetrazole }}\right) .-{ }^{13} \mathrm{C}$ NMR (101 MHz, [D $\left.] \mathrm{DMSO}\right)$ : $\delta=165.0\left(C_{\mathrm{q}, \text { tetrazole }}-\mathrm{N} 1^{\prime}-\mathrm{N} 2^{\prime}-\mathrm{CH}_{2}\right), 154.6\left(C_{\mathrm{q} \text {,tetrazole }}-\mathrm{N} 1-\mathrm{CH}_{2}\right)$, $131.8\left(\mathrm{~N} 1-\mathrm{CH}_{2}-\mathrm{CH}=\right), 131.3\left(\mathrm{~N}^{\prime}-\mathrm{CH}_{2}-\mathrm{CH}=\right), 120.2\left(\mathrm{~N}^{\prime}-\right.$ $\left.\mathrm{CH}_{2}-\mathrm{CH}=\mathrm{CH}_{2}\right), 119.1\left(\mathrm{~N} 1-\mathrm{CH}_{2}-\mathrm{CH}=\mathrm{CH}_{2}\right), 55.1\left(\mathrm{N2}^{\prime}-\mathrm{CH}_{2}-\right)$, $49.1\left(\mathrm{~N} 1-\mathrm{CH}_{2}-\right), 22.7\left(\mathrm{CH}_{2}-\mathrm{C}_{\mathrm{q} \text {,tetrazole }}\right), 21.5\left(\mathrm{CH}_{2}-\mathrm{C}_{\mathrm{q} \text {,tetrazole }}\right)$. HRMS ((+)-ESI): $m / z=247.1412$ (calcd. 247.1414 for $\mathrm{C}_{10} \mathrm{H}_{15} \mathrm{~N}_{8}$, $\left.[\mathrm{M}+\mathrm{H}]^{+}\right) .-\mathrm{C}_{10} \mathrm{H}_{14} \mathrm{~N}_{8}$ (246.27): calcd. C 48.77, H 5.73, N 45.50; found C 48.75, H 5.70, N 44.73 .

\subsection{Crystal structure determination}

The crystallographic data were collected using an Oxford XCalibur3 diffractometer equipped with a Spellman generator (voltage $50 \mathrm{kV}$, current $40 \mathrm{~mA}$ ) and a Kappa CCD area detector was employed for data collection using MoK $\alpha$ radiation $(\lambda=0.71073 \AA)$. An absorption correction was applied based on multi-scans. The structure was solved by Direct Methods using SIR-97 [41], refined with SHELXL-97 [42], finally checked using the Platon software [43] integrated in the WINGX software suite [44]. All
$\mathrm{H}$ atoms were located from a Fourier map and refined isotropically, with $U_{\text {iso }}(\mathrm{H})=1.2 U_{\text {eq }}(\mathrm{N}, \mathrm{O})$. All non-hydrogen atoms were refined anisotropically. DiAmond [45] plots are showing displacement ellipsoids at the $50 \%$ probability level for the non-hydrogen atoms. Table 1 contains the crystal data and numbers pertinent to data collection and structure refinement.

CCDC 1484921 contains the supplementary crystallographic data for this paper. These data can be obtained free of charge from The Cambridge Crystallographic Data Centre via www.ccdc.cam.ac.uk/data_request/cif.

\section{Supporting information}

The spectra of the HMQC and HMBC 2D NMR measurements (Figs. S1-S4), together with detailed discussions of the methods used for calculations are given as Supporting Information available online (DOI: 10.1515/znb-2016-0146).

Acknowledgments: Financial support of this work by the Ludwig-Maximilian University of Munich (LMU), the Office of Naval Research (ONR) under grant no. ONR. N00014-16-1-2062, and the Bundeswehr - Wehrtechnische Dienststelle für Waffen und Munition (WTD 91) under grant no. E/E91S/FC015/CF049 is gratefully acknowledged. The authors acknowledge collaborations with Dr. Mila Krupka (OZM Research, Czech Republic) in the development of new testing and evaluation methods for energetic materials and with Dr. Muhamed Suceska (Brodarski Institute, Croatia) in the development of new computational codes to predict the detonation and propulsion parameters of novel explosives. We are indebted to and thank Drs. Betsy M. Rice, Jesse Sabatini and Brad Forch (ARL, Aberdeen, Proving Ground, MD, USA) for many inspiring discussions. Stefan Huber is thanked for assistance with sensitivity measurements. Christina Hettstedt and Carolin Pflüger are thanked for help with $\mathrm{X}$-ray diffraction measurements.

\section{References}

[1] E. Makino, N. Iwasaki, N. Yagi, T. Ohashi, H. Kato, Y. Ito, H. Azuma, Chem. Pharm. Bull. 1990, 38, 201.

[2] C. V. Reddy Sastry, Ind. J. Chem. 1990, 29B, 396.

[3] C. T. Alabaster, J. Med. Chem. 1989, 32, 575.

[4] M. Uchida, M. Komatsu, S. Morita, T. Kanbe, K. Nagakawa, Chem. Pharm. Bull. 1989, 37, 322.

[5] K. Matyjaszewski, B. S. Sumerlin, N. Tsarevsky, J. Spanswick, Int. Patent 2005087818, 2005. 
[6] F. Mwale, P. -L. Girard-Lauriault, H. T. Wang, S. Lerouge, J. Antoniou, M. R. Wertheimer, Tissue Eng. 2006, 12, 2639.

[7] F. Truica-Marasescu, M. R. Wertheimer, Plasma Process. Polym. 2008, 5, 44.

[8] S. R. Ganta, G. K. Williams, C. G. Miller, WO 2008054531, 2008.

[9] P. S. Khandhadia, H. Mizuno, US 2008078486, 2008.

[10] D. Fischer, T. M. Klapötke, J. Stierstorfer, Angew. Chem. Int. Ed. 2014, 53, 8172.

[11] S. Huber, D. Izsák, K. Karaghiosoff, T. M. Klapötke, S. Reuter, Propellants, Explos., Pyrotech. 2014, 39, 793.

[12] J. W. Fronabarger, M. D. Williams, W. B. Sanborn, J. G. Bragg, D. A. Parrish, M. Bichay, Propellants, Explos., Pyrotech. 2011, 36, 541.

[13] N. Fischer, D. Fischer, T. M. Klapötke, D. G. Piercey, J. Stierstorfer, J. Mater. Chem. 2012, 22, 20418.

[14] N. Fischer, D. Izsák, T. M. Klapötke, S. Rappenglück, J. Stierstorfer, Chem. Eur. J. 2012, 18, 4051.

[15] H. Bendler, H. Gawlick, G. Marondel, W. Siegelin, US 3468730A, 1968.

[16] Bundesanstalt für Materialforschung (BAM), http://www.bam. de (accessed: 13/06/2016); laying down the test methods pursuant to Regulation (EC) No. 1907/2006 of the European Parliament and of the Council on the Evaluation, Authorisation and Restriction of Chemicals (REACH), ABI. L 142, 2008.

[17] NATO Standardization Agreement (STANAG) on Explosives, Impact Tests, No. 4489, $1^{\text {st }}$ edition, Sept. 17th, 1999.

[18] WIWEB-Standardarbeitsanweisung 4-5.1.02, Ermittlung der Explosionsgefährlichkeit, hier: der Schlagempfindlichkeit mit dem Fallhammer, Nov. $8^{\text {th }}, 2002$.

[19] NATO Standardisation Agreement (STANAG) on Explosives, Friction Tests, No. 4487, $1^{\text {st }}$ edition, Aug. $22^{\text {nd }}, 2002$.

[20] WIWEB-Standardarbeitsanweisung 4-5.1.03, Ermittlung der Explosionsgefährlichkeit, hier: der Reibempfindlichkeit mit dem Reibeapparat, November $8^{\text {th }}, 2002$.

[21] T. M. Klapötke, B. Krumm, N. Mayr, F. X. Steemann, G. Steinhauser, Safety Science 2010, 48, 28.

[22] Test methods according to the UN Manual of Tests and Criteria, Recommendations on the Transport of Dangerous Goods, United Nations Publication, New York, Geneva, $4^{\text {th }}$ revised edition, 2003.

[23] G. Steinhauser, K. Tarantik, T. M. Klapötke, J. Pyrotech. 2008, 27, 3.

[24] A. Hammerl, G. Holl, T. M. Klapötke, P. Mayer, H. Nöth, H. Piotrowski, M. Warchhold, Eur. J. Inorg. Chem. 2002, 4, 834.

[25] T. M. Klapötke, J. Stierstorfer, K. R. Tarantik, I. D. Thoma, Z. Anorg. Allg. Chem. 2008, 634, 2777.

[26] E. -C. Koch, J. Pyrotech. 2001, 13, 1.

[27] S. M. Sproll, Dissertation, Ludwig-Maximilians-Universität München, München 2009.

[28] F. M. Betzler, Dissertation, Ludwig-Maximilians-Universität München, München 2013.
[29] E. Pasquinet, in New Polymers for Special Applications, (Ed.: A. DeSouza Gomes), InTech, Rijeka (Croatia), 2012, chapter 10, pp. 313.

[30] W. G. Finnegan, R. A. Henry, S. Skolnik, US 3,004,959, 1985.

[31] R. C. Tuites, T. E. Whiteley, L. M. Minsk, US 245,614, 1971.

[32] Z. P. Demko, K. B. Sharpless, J. Org. Chem. 2001, 66, 7945.

[33] P. A. Aleshunin, U. N. Dimitrieva, V. A. Ostrovskii, Russ. J. Org. Chem. 2011, 47, 1882.

[34] A. F. Holleman, E. Wiberg, N. Wiberg, Lehrbuch der Anorganischen Chemie, de Gruyter, New York 2007.

[35] C. A. K. Diop, M. F. Mahon, K. C. Molloy, L. Ooi, P. R. Raithby, M. M. Venter, S. J. Teat, Cryst. Eng. Comm. 2002, 4, 462.

[36] M. J. Frisch, G. W. Trucks, H. B. Schlegel, G. E. Scuseria, M.A. Robb, J. R. Cheeseman, V. B. Scalmani, B. Mennucci, G. A. Petersson, H. Nakatsuji, M. Caricato, X. Li, H. P. Hratchian,A.F. Izmaylov, J. Bloino, G. Zheng, J. L. Sonnenberg,M. Hada,M. Ehara, K. Toyota, R. Fukuda, J. Hasegawa, M. Ishida, T. Nakajima, Y. Honda, O. Kitao, H. Nakai, T. Vreven,J.A. Montgomery, J. E. Peralta, F. Ogliaro, M. Bearpark, J.J. Heyd,E. Brothers, K. N. Kudin, V. -N. Staroverov, R. Kobayashi,J. Normand, K. Raghavachari, A. Rendell, J. C. Burant,S.S. Iyengar, J. Tomasi, M. Cossi, N. Rega, J. M. Millam, M. Klene,J.E. Knox, J. B. Cross, V. Bakken, C. Adamo,J. Jaramillo,R. Gomperts, R. E. Stratmann, O. Yazyev, A. J. Austin, R. Cammi,C. Pomelli, J. W. Ochterski, R. L. Martin,K. Morokuma, V. G. Zakrzewski, G. A. Voth, P. Salvador,J. J. Dannenberg, S. Dapprich, A. D. Daniels, Ö. Farkas, J. B. Foresman, J. V. Ortiz, J., J. Cioslowski, D. J. Fox, GAUSSIAN 09 (rev. A.03 ed.); Gaussian, Inc., Wallingford CT (USA) 2009.

[37] J. W. Ochterski, G. A. Petersson, J. A. Montgomery Jr., J. Chem. Phys. 1996, 104, 2598.

[38] J. A. Montgomery Jr., M. J. Frisch, J. W. Ochterski, G. A. Petersson, J. Chem. Phys. 2000, 112, 6532.

[39] M. Sućeska, Propellants, Explos., Pyrotech. 1991, 16, 197.

[40] M. Sućeska, Expl05 (version 6.02), Zagreb (Croatia), 2013.

[41] A. Altomare, M. C. Burla, M. Camalli, G. L. Cascarano, C. Giacovazzo, A. Guagliardi, A. G. G. Moliterni, G. Polidori, R. Spagna, J. Appl. Crystallogr. 1999, 32, 115.

[42] G. M. Sheldrick, Acta Crystallogr. 2008, A64, 112.

[43] A. Spek, Acta Crystallogr. 2009, D65, 148.

[44] L. J. Farrugia, J. Appl. Cryst. 1999, 32, 837.

[45] K. Brandenburg, DiAmond, Crystal and Molecular Structure Visualization, Crystal Impact - H. Putz \& K. Brandenburg GbR, Bonn (Germany) 2012. See also: http://www.crystalimpact. com/diamond/.

Supplemental Material: The online version of this article (DOI: 10.1515/znb-2016-0146) offers supplementary material, available to authorized users. 